(c) www.ijrbat.in

\title{
PALYNOLOGICAL STUDIES IN CYPERUS FROM CYPERACEAE OF CHANDRAPUR DISTRICT, MAHARASHTRA, INDIA.
}

\author{
KUNJALWAR S.G ${ }^{1 . N I K H A D E ~ C . A .2 . ~}$ \\ 1-Professor, Department of Botany, Nutan Adarsh Arts, Commerce and \\ Smt.M.H.Wegad Science College, Umred. Dist. Nagpur. \\ 2-Principal, Chintamani College of Arts \& Science Gondpipri .Dist. Chandrapur \\ .Maharashtra. India \\ E-mail: drcanikhade@gmail.com
}

Communicated: 17.03 .21

\begin{abstract}
:
There is advantages in using pollen grains as a valuable source of characters in systematic studies.Cyperus is an important genus of Cyperaceae.In the present study five species of Cyperus have been selected for pollen morphological studies ,The species chosen are C.alopecuroides Rottb., C.alulatus Kern,C.iria Linn, C.compressus Linn,C.nutans Vahl. Pollen grains of Cyperaceae are oblate spheroidal to perprolate in shape, inaperturate to polyporate with opercula or pontopercula on pori or colpi.Apertures occur in all species investigated. Pollen morphological variation within Cyperus is considerable
\end{abstract}

Keywords: Apertures; Cyperaceae, Exine, Pollen, sedges and palynology.

\section{INTRODUCTION:}

Cyperaceae is the third largest family in the monocotyledons consisting of 109 genera and approximately 5,500 species (Govaerts et al. 2007). Recent phylogenetic studies based on molecular data have suggested to maintain only two subfamilies within Cyperaceae: Mapanioideae and Cyperoideae (Simpson et al. 2008; Muasya et al. 2008). In this new delimitation Mapanioideae comprise two tribes: Hypolytreae and Chrysitricheae, while the circumscription of Cyperoideae changed considerably to include taxa previously placed in Caricoideae and Sclerioideae (sensu Goetghebeur 1998).

The palynology of Cyperaceae attracted quite some attention in the past, mainly because of the occurence of an unusual type of simultaneous microsporogenesis, which leads to the formation of pseudomonads (Selling 1947; Davis 1966) or kryptotetrads (Erdtman 1952). After meiosis of the microspore mother cell, one of the four nuclei enlarges and occupies the center of the coenocytic cell, while the other three nuclei migrate to the narrow apex where they are separated by septa and subsequently degenerate (Shah 1962; Dunbar 1973; Strandhede 1973; Furness and Rudall 1999; Brown and Lemmon 2000; Simpson et al. 2003). This unusual pattern of microsporogenesis is only known in one other unrelated group: tribe Styphelieae in Ericaceae (Smith-White 1959).

Several authors have recognized different pollen types in Cyperaceae mainly based on pollen shape, pollen size, and number and type of apertures. However, the number of species investigated with scanning electron microscope (SEM) is very limited and the recent availability of a Cyperaceae phylogeny offers great potential for evolutionary interpretations of the data. The major aim of the present study is to provide a palynological overview at genera and family level in order to document with scanning electron microscopy, the pollen and or bicule morphology. Our data will be used to assess the taxonomically useful characters, and to determine palynological 
evolutionary trends in Cyperaceae as Cyperus is important genus with important pollen type as recognized in this study.

\section{MATERIAL \& METHODS}

For pollen morphological study fresh material was collected from villages of Chandrapur district. The matured anthers were collected and kept in small vials containing $70 \%$ alcohol. When the polliniferous material was taken from herbarium sheets, spikes were initially boiled in water for minutes, stamens separated and collected and preserved in $70 \%$ alcohol for atleast a few hours before proceeding for acetolysis method of Erdtman(1952).

A total of 05 species of Cyperus have been investigated in present study. The polliniferous material in the $70 \%$ alcohol was crushed with the help of glass rod for 2-4 minutes, shaken well and transferred to centrifuge tubes through a mesh (48 meshes/c.m. size). Pollen material was centrifuged at $3000 \mathrm{rpm}$. for 3 minutes and decanted off. In centrifuged pollen material, $5 \mathrm{ml}$ glacial acetic acid was added, again centrifuged and decanted off.

Acetolysis mixture was then poured in the tubes. The acetolysis mixture was prepared by taking 9 parts of acetic anhydride and 1 part concentrated sulphuric acid, added drop by drop. The tubes with the acetolysis mixture were stirred well and kept in water bath at $70^{\circ} \mathrm{c}$.The water was then allowed to boil for 2-4 minutes till the mixture in tubes turns golden brown in colour. The acetolysis mixture in tubes, after cooling was again centrifuged and completely decanted off. Then 5 $\mathrm{ml}$ of glacial acetic acid was poured in the tubes, centrifuged, a mixture was made of $2 \mathrm{ml}$ of glacial acetic acid, 2-3 drops of saturated Sodium Chlorate/ Potassium chlorate solution followed by 1-2 drops of concentrated $\mathrm{HCl}$. Such prepared chlorination mixture was then poured in the tubes containing pollen material (Nair, 1960). During chlorination process, chlorine was evolved within few minutes, which bleached the pollen material. By this method the exine became clearly visible for observation. The mixture was then centrifuged and decanted off and then pollen material in tubes was washed with distilled water and centrifuged again. Finally dilute glycerine containing glycerine and distilled water in equal parts was added in the tubes. This mixture was shaken thoroughly in order to disperse the pollen equally. This is allowed to stand to 1 hour, centrifuged, decanted off and the pollen were mounted in the glycerine jelly.

\section{RESULT AND DISCUSSION - OBSERVATIONS \\ Cyperus alopecuorides Rottb.}

Pollen LM. Heteropolar, assymetrical, bicolpate, oval, 2-3 pores, folded, size $42.5 \mu$ range $40 \mu$ to $45 \mu$, rather large, oblate, spheroidal, exine $2 \mu$ thick, exine surface granular.

\section{Cyperus alulatus Kern.}

Pollen LM. Heteropolar, assymetrical, oval, monocolpate, folded, size $40 \mu$ range $35 \mu$ to $45 \mu$ rather large, prolate, exine $1.5 \mu$, thick, exine surface granular.

\section{Cyperus compressus Linn.}

Pollen LM. Heteropolar, assymetrical, monocolpate, folded, spherical, colpus on broad side, $1-2$ porate, size $47.5 \mu$ range $45 \mu$ to $50 \mu$, rather large, prolate spheroidal, exine $2 \mu$, thick, surface granular, LO pattern.

\section{Cyperus iria Linn.}

Pollen LM. Heteropolar, assymetrical, monocolpate, 1-2 porate, folded, size, $47.5 \mu$ range $45 \mu$ to $50 \mu$, colpus on broader side, exine $1.5 \mu$ thick, prolate, spheroidal, surface of exine granular.

Cyperus nutans Vahl .

Pollen LM.Heteropolar, assymetrical, spherical, ellipsoidal, monocolpate, $2-3$ porate, size $32.5 \mu$ range $30 \mu$ to $35 \mu$, medium, folded, prolate, spheroidal, exine $1.5 \mu$ thick, surface granular faint.

\section{DISCUSSION:}

The Cyperaceae is a subject of intensive researches because of peculiar course of pollen 
development. The pollen grains are called 'Pseudomonad' (Selling 1947), Cryptotetrad (Erdtman, 1952), or Monad (Cronquist 1968). The pollen morphology in the family has been studied by Wodehouse (1935), Erdtman (1952), Kuprianova (1948), Sharma (1967), Padhye (19661967), Nair (1970), Padhye and Makde (1980), Kunjalwar (2008).

While summarising the pollen-morphological investigations on Cyperaceae; Erdtman (1952) stated that the Cyperaceae shows two patterns of pollen, the Carex, and Cyperus type. Carex type is characterised by the presence of one ulceroid aperture at the thick end and three lateral faintly marked poroid or elongate apertures on the lateral sides, is the commonest aperture type in the family. In Cyperus type a prominent colpus is present at the broader end and it is the dominant character in the family.

The present study indicates that in a Cyperus alopecuroides Rottb., Cyperus alulatus Kern, Cyperus iria Linn, Cyperus compressus Linn, Cyperus nutans Vahl show the Cyperus type of pollen.

Erdtman (1952) who reported such a pattern in Mapania and allied genera, considered it somewhat puzzling for Cyperaceae. The present findings, however, clearly show that the monocolpate condition of the pollen in the family which appeared a puzzle to Erdtman (1952) is all the same quite dominant.

It thus appears that the Cyperaceae shows two patterns of pollen; the Carex and the Cyperus types. The later seems to be evolved from the former by elimination of lateral aperture and therefore more evolved. The faintly marked poroid or elongate apertures or colpoid streaks seen in various taxa showing Carex type (Erdtman 1952), Cyperus rotundus (Sharma 1967) and Pycreus latespicatus, $P$. puncticulatus and Cyperus imbricatus ( Padhye \& Makde 1980) lends further support to this contention.

The pollen of Cyperaceae possess thin exine that is scanty ornamented. Grains are often tenuiexinous with sexine as thick or slightly thicker than nexine (Erdtman, 1952). Mostly LO Pattern is encountered though exceptionally LO Pattern is typically seen in Hypolytrium schraderianum. The present study confirms that exine stratification is simple, being mostly foveolate or granular.

Erdtman (1966) pointed out that the aperture type with one ulceroid aperture at the thick end and three lateral, \pm faintly marked poroid or elongate apertures, is the most frequent type within the Cyperaceae ( the Carex - type). He also stated that the genus Mapania and several others differ from the rest of the Cyperaceae because mapanoid pollen grains are spheroidal and only have one distinct aperture, an ulcus.

Haines and Lye (1983) translated this distinction into two major type, the Mapania - type (found only in the tribe Hypolytreae) and the Carex - type (found in vast majority of sedges).

Koyama (1961) distinguished three pollen grain types within the Cyperaceae.

(a) apple-shaped, $1+3$ or $1+6$ aperturate (most of the Cyperaceae).;

(b) Spheroidal, polyforate (representative of the genus Machaerina);

(c) Spheroidal, inaperturate (representatives of the genus Hypolytrum).

Padhye and Makde (1980) distinguished two types : the Cyperus - type with one distal colpus and the Carex-type as defined by Erdtman (1952). The Cyperus - type was found among members of the following genera: Bulbostylis, Courtoisina, Cyperus p.p., Eleocharis, Fimbristylis, Rhynchospora and Scirpus s.l. (= Schoenoplectus). The carex type was found only in Cyperus imbricatus and members of Pycreus and Lipocarpha.

Dahlgren \& Clifford (1982) stated that the majority of the pollengrains of Cyperaceae are ulcerate, with some of them still presenting 3 lateral pores or long thinnings.

Fernandez (1987) distinguished 6 types of pollen grains among the Cyperaceae but her typology is based on a study of only 19 species only. The following types were recognized: Cyperus longustype (Panto aperturate with 1 distal pore and 4-6 Colpi); Cyperus michelianus - type (Panto- 
aperturate with several pores); Cladium mariscus

- type (inaperture); Shoenus nigricans - type (Pantoaperturate with 1 distal pore and 4-5 colpi); Carex hallerana - type (Panto aperturate with 1 distal pore and 4-5 equatorial pores). Bruhl (1995) distinguished two groups of pollengrain types within the Cyperaceae,either with few (1-6) aperture

(some 20-genera) or with many $(>6)$ apertures (only Baumea, Machaerina and Tricostularia).

More recently, van Wichelen et al., (1999), using LM and SEM analysis of representatives from the four sub families of Cyperaceae (Classification after Goetghebeur, 1986), singled out the groups of Mapanioideae (anaulcerate, frequently spheroidal \pm thick walled pollengrains). Sclerioideae - Caricoideae (anaulcerate with three lateral pores or colpi, mostly broadly obovoid and thin walled pollen grains) and Cyperoideae (anaulcerate with several lateral pores or colpi, mostly obovoid and thin walled pollen grains). The last of these groups appeared heterogeneous, perhaps distinguishable in species with lateral colpi and species with lateral pores.

Ontogeny of pollen grains in Cyperaceae is nearly unique among angiosperms (van Wichelan et al., 1999): microsporogenesis is simultaneous (Furness \& Rudall, 1999) and only one meiotic nucleus of a tetrad survives to form a pseudomonad (Selling, 1947) but these characteristics seem independent of the nature of the pollen grain wall (van Wichelan et al., 1999) and of aperture type (Furness and Rudall, 1999), respectively.

Up till now only fragmentary data on the morphology of pollengrains of Cyperaceae have been published. This data are often based on few genera or species and the resulting typologies are insufficient to answer the question whether pollen grain morphological characters could be of taxonomic value in the Cyperaceae.

\section{REFERENCE}

Brown RC, Lemmon BE (2000) The cytoskeleton and polarization during pollen development in Carex blanda (Cyperaceae). Amer $\mathrm{J}$ Bot $87: 1-11$

Bruhl JJ (1995) Sedge genera of the worldrelationships and a new classification of the Cyperaceae. Austral Syst Bot 8:125-305

Cronquist, A. 1968 The Evolution \& Classification of Flowering plants Nelson, London. U.K.

Dahlgren RMT, Clifford HT, Yeo PF (1985) The families of the monocotyledons. Academic Press, London

Davis GL (1966) Systematic embryology of the angiosperms. Wiley, New York

Dunbar A (1973) Pollen development in Eleocharis Palustris Group (Cyperaceae).

1. Ultrastructure and ontogeny. Bot Not 126:197254

Erdtman G (1952) Pollen morphology and plant taxonomy. Almqvist \& Wiksell, Stockholm

Erdtman G (1966) Pollen morphology and plant taxonomy. Angiosperms. Hafner, New York.

Fernandez I (1987) Contribution al conocimiento palinologico de Cyperaceae.

Acta Bot Malacitana 12:173-182

Furness CA, Rudall PJ (1999) Microsporogenesis in monocotyledons. Ann Bot 84:475-499.

Goetghbeur, P. (1986) Genera Cyperacearum. Een bijdrage tot de Kennis van de morfologie, systematick en fylogenese van de Cyperaceae genera - DPhil. Thesis. State University of Ghent, Belgium.

Goetghebeur P (1998) Cyperaceae. In: Kubitzki K (ed) The families and genera of vascular plants. Flowering plants-monocotyledons, vol 4. Springer, Berlin, pp 141-190

Govaerts R, Simpson DA, Goetghebeur P, Wilson K, Egorova T, Bruhl JJ (2007) World checklist of Cyperaceae. The Board of Trusteeds of the Royal Botanic Gardens, Kew. Available at http://www.kew.org/wcsp/monocots/, Accessed on 1 October 2007

Haines RW, Lye KA (1983) The sedges and rushes of East Africa. African Natural History Society, Nairobi 
Koyama T. 1961 Classification of family Cyperaceae 1. J. Fac. Sci. Univ. Tokyo 8 (3). 37-148.

Kunjalwar S.G.(2008 ) Scanning electron microscopy as aid to the taxonomy of sedges: sporoderm and spermoderm pattern in some Cyperaceae of Nagpur District ,Ph.D. Thesis Rashtrasant Tukadoji Maharaj Nagpur Univrsity Nagpur .India

Kuprianova, L.A. 1948 Pollen morphology and the phylogeny of the monocotyledons. Comm. Komorrow. Indst. Acad. Sci. 1:7.

Muasya AM, Simpson DA, Verboom GA, Goetghebeur P, Naczi RFC, Chase MW, Smets E (2008) Phylogeny of cyperaceae based on DNA sequence data: current progress and future prospects.

Nair P. K. K. (1970) Pollen morphology of Angiosperms. Vikas Publication, Delhi.

Padhye M.D. (1966-67) The pollen grains of Kyllinga Rottb. Palynological Bull. vol. II \& III. pp. $101-103$.

Padhye MD, Makde KH (1980) Pollen morphology of Cyperaceae. J Palynol 16:71-81

Selling OH (1947) Studies in the Hawaiian pollen statistics, Part II. The pollens of the Hawaiian phanerograms. Bulletin of the Bishop Museum. Honolulu 38:1-360

Shah CK (1962) Pollen development in some members of the Cyperaceae. Plant embryology-a symposium. CSIR, New Delhi, pp 81-93

Sharma, M. 1967 Pollen morphology of Indian Monocotyledons J. Palynol Special Volume.
Simpson DA, Furness CA, Hodkinson TR, Muasya AM, Chase MW (2003) Phylogenetic relationships in Cyperaceae subfamily Mapanioideae inferred from pollen and plastid DNA sequence data. Amer $\mathrm{J}$ Bot 90:1071-1086

Simpson DA, Muasya AM, Alves M, Bruhl JJ, Dhooge S, Chase MW, Furness CA, Ghamkhar K, Goetghebeur P, Hodkinson TR, Marchant AD, Nieuborg R, Reznicek AA, Roalson EH, Smets E, Starr JR, Thomas WW, Wilson KL, Zhang X (2008) Phylogeny of Cyperaceae based on DNA sequence data-a new rbcL analysis. In: MonocotsIII/Grasses IV. Claremont, CA: Aliso 23: 72-83

Smith-White S (1959) Pollen development patterns in the Epacridaceae. Proc Linn Soc NSW 84:8-35

Strandhede SO (1973) Pollen development in Eleocharis Palustris Group (Cyperaceae). 2. Cytokinesis and microspore degeneration. Bot Not 126:255-265

Van Wichelen J, Camelbeke K, Chaerle P, Goetghebeur P, Huysmans S (1999) Comparison of different treatments for LM and SEM studies and systematic value of pollen grains in Cyperaceae. Grana 38:5058

Wodehouse RP (1935) Pollen grains. Their structure identification and significance in science and medicine. Hafner, New York

04-05 


\section{Photo Plate - 1}
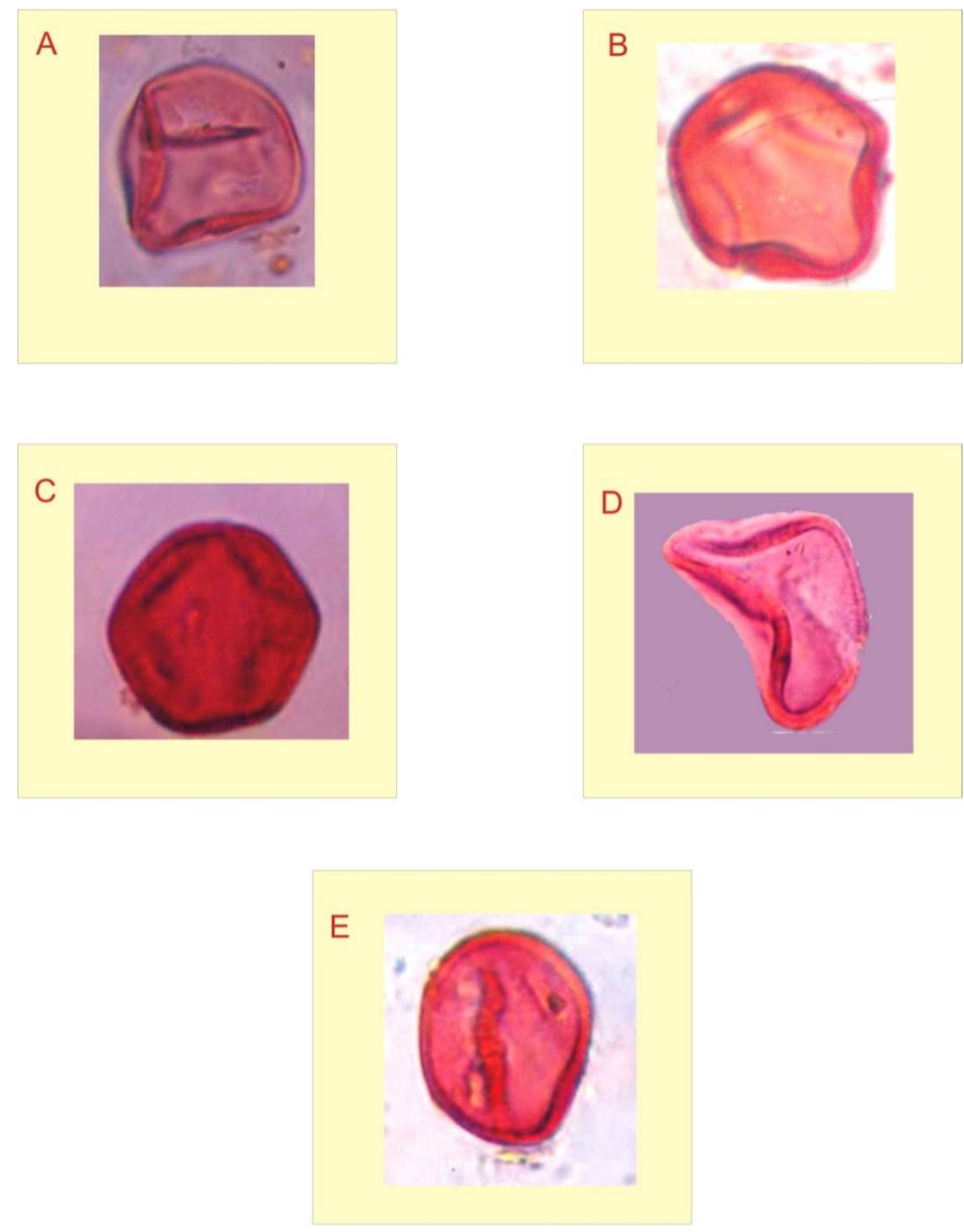

Pollen grains Light Microscopy
A. Cyperus alopecuroides Rottb.
B. C. alulatus Kern.
C. C. compressus Linn.
D. C. iria Linn.
E. C. nutans Vahl. 